\title{
TRƯỜNG HỢP BỆNH NHÂN HO RA MÁU NặNG, HIỂM GặP ĐƯợC CÚU SỐNG TẠI BỆNH VIỆN PHỔI TRUNG ƯƠNG
}

Đinh Văn Lượng*, Đinh Văn Tuấn*, Đặng Duy Đức*, Nguyễn Lê Vinh*,
Nguyễn Thành Long*, Nguyễn Viết Nghĩa*

\section{I. ĐẶT VẤN ĐỀ}

Ho ra máu là máu khạc ra từ dưới thanh môn trở xuống, một triệu chứng thường gặp nhưng có rất nhiều nguyên nhân. Ho ra máu nặng được định nghĩa là khi lượng máu ho ra từ $>100$ đến $>600 \mathrm{ml}$ trong 24 giờ. Ho ra máu nặng thường là dấu hiệu của một bệnh nặng và có thể gây tử vong do ngạt và tắc nghẽn đường thở. Ho ra máu nặng chiếm khoảng $5 \%$ các trường hợp ho ra máu và tỷ lệ tử vong lên tới $80 \%$.

Tại Bệnh viện Phổi trung ương đã điều trị nhiều trường hợp ho ra máu nặng bằng phẫu thuật cùng với sự phối hợp của nhiều chuyên khoa khác nhau (Hồi sức tích cực, các phương pháp điều trị nội khoa mới nhất, nút mạch, nội soi can thiệp, ...), đã cứu chữa thành công rất nhiều bệnh nhân ho ra máu nặng với nhiều nguyên nhân khác nhau như do di chứng lao phổi, u nấm phổi, giãn phế quản, ung thư phế quản, nhồi máu phổi, các dị tật bẩm sinh phổi, ...).

Tháng 02/2018 vừa qua, Bệnh viện tiếp nhận một trường hợp ho ra máu nặng có nguy cơ tử vong rất cao. Bệnh nhân được cứu chữa thành công nhờ sự chỉ đạo trực tiếp của Giám Đốc Bệnh viện, sự phối hợp tích cực của nhiều chuyên Khoa, kíp phẫu thuật và việc ứng dụng các kỹ thuật, công nghệ cao trong chẩn đoán, điều trị. Mặc dù tại bệnh viện chuyên khoa đầu ngành về hô hấp, ho ra máu nặng không quá hiếm song trường hợp này lại có rất đặc biệt.

\section{GIỚI THIỆ TRƯờNG HỢP LÂM} SÀNG

Bệnh nhân nam 35 tuổi, tiền sử khỏe mạnh. Diễn biến trước vào viện 2 giờ, đột ngột ho ra máu 3 lần, mỗi lần $5 \mathrm{ml}$ máu đỏ tươi, đông ngay; vào Bệnh viện Phổi trung ương (ngày
27/01/2018) trong tình trạng tỉnh táo, tiếp xúc tốt, thể trạng gầy, da niêm mạc nhợt, không sốt, không ho ra máu, không khó thở, rì rào phế nang giảm ở đáy phổi phải.

- Xét nghiệm công thức máu: $\mathrm{HC}=4,3$ $\mathrm{T} / 1 ; \mathrm{HGB}=135 \mathrm{~g} / \mathrm{l} ; \mathrm{HCT}=38 \% ; \mathrm{BC}=6,96 \mathrm{G} / 1$ $(\mathrm{Neu}=63,5 \%, \mathrm{Lym}=25,6 \%$, Mono $=10,5 \%)$.

- Xét nghiệm vi sinh đờm (vi khuẩn lao và ngoài lao, nấm) đều âm tính. *

- Chẩn đoán hình ảnh khi nhập viện.

$+\mathrm{X}$. Quang phổi chuẩn:

* Nốt mờ không đồng nhất rải rác hai phổi, tập trung nhiều đáy phổi phải

* Không rõ dấu hiệu giảm thể tích phổi.

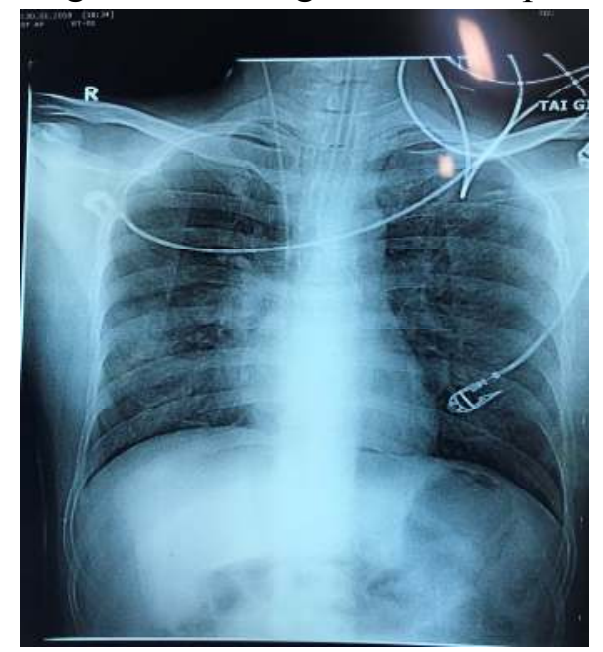

Hình ảnh XQ phổi thẳng

+ CLVT lồng ngực (29/01/2018): Đông

đặc kèm nốt nhu mô thùy dưới phổi phải, kính mờ rải rác ưu thế phần thất 2 phổi. Theo dõi giãn động mạch phân thùy 6 phổi phải.

* Bệnh viện Phổi trung Uơng

Ngưòi chịu trách nhiệm khoa học: TS. Đinh Văn Luợng

Ngày nhận bài: 01/05/2018 - Ngày Cho Phép Đăng: 20/05/2018

Phản Biện Khoa học: GS.TS. Bùi Đức Phú

PGS.TS. Đặng Ngọc Hùng 

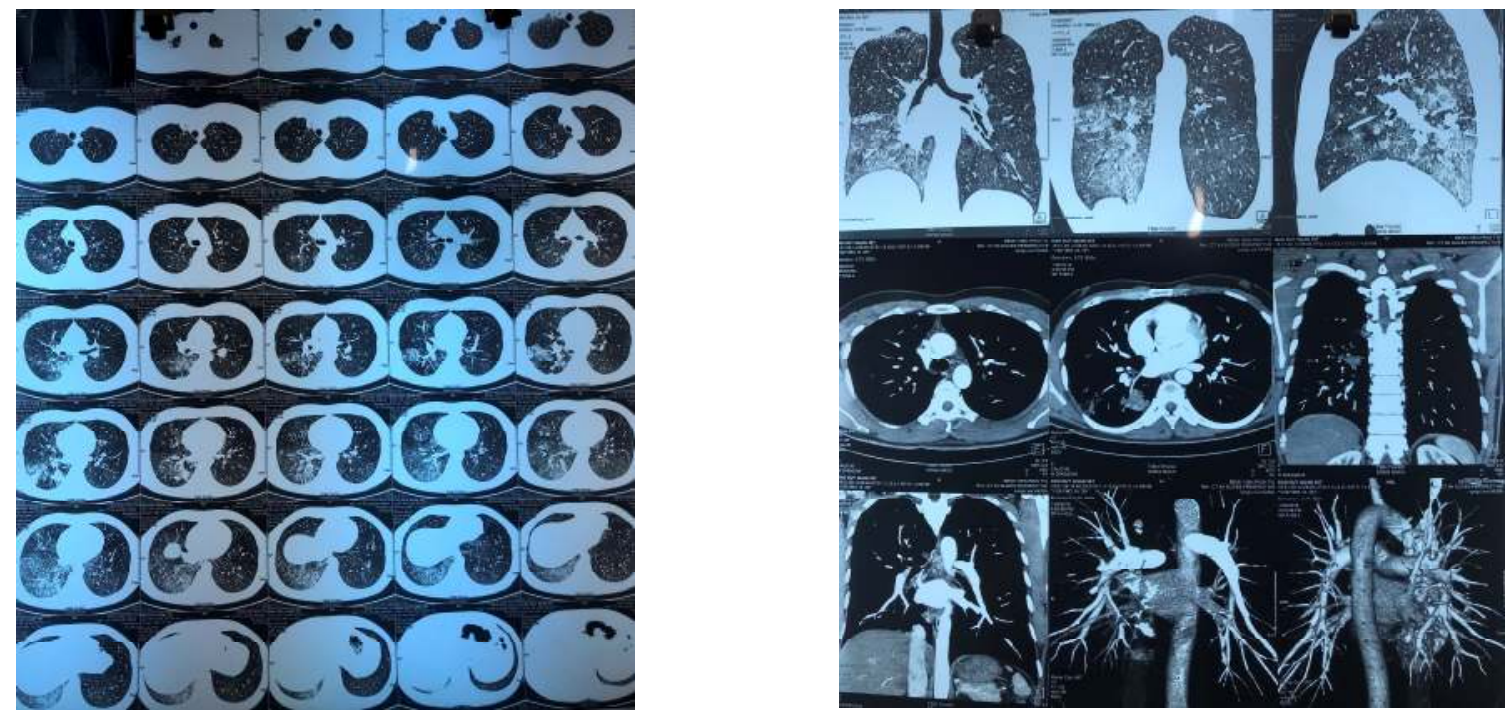

Hìn ảnh CLVT phổi (29/01/2018)

- Xét nghiệm Gene-expert đờm (29/01/2018): kết quả âm tính.

- Điều trị: Kháng sinh, truyền dịch, truyền máu, thuốc cầm máu, giảm ho, an thần. Tuy nhiên (29 - 30/01/2018) bệnh nhân lại xuất hiện ho ra máu 2 lần $(500 \mathrm{ml}) /$ ngày; Tinh thần mệt mỏi, ho khạc đờm kém, khó thở liên tục, tim nhịp nhanh đều, huyết áp 120/70 mmHg, rì rào phế nang giảm đáy phổi phải.
Xét nghiệm công thức máu: $\mathrm{HC}=2,7 \mathrm{~T} / 1$; $\mathrm{HGB}=83 \mathrm{~g} / \mathrm{l} ; \mathrm{HCT}=24 \% ; \mathrm{BC}=8,75 \mathrm{G} / \mathrm{l} ; \mathrm{Neu}=$ $76,8 \% ; \mathrm{Lym}=17,4 \%$; Mono $=5,8 \%$.

- Hình ảnh X quang phổi chuẩn (31/01/2018):

* Nốt mờ đáy phổi phải

* Không rõ dấu hiệu giảm thể tích phổi.

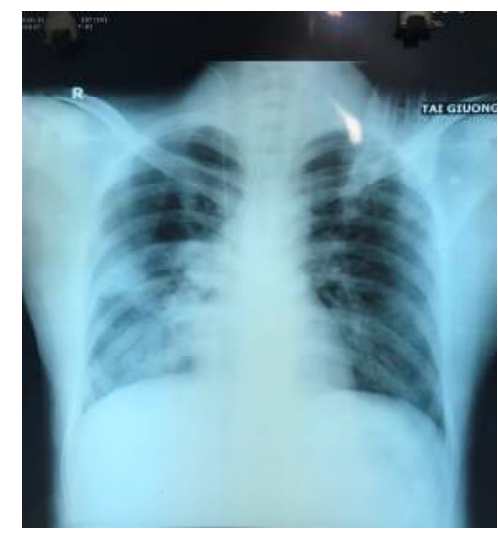

\section{Hình ảnh $X Q$ phổi thẳng}

Trước tình hình diễn biến phức tạp của phối hợp kíp phẫu thuật và nội soi can thiệp (với bệnh, nguy cơ suy hô hấp, tử vong cao. Dưới sự chỉ đạo của Giám đốc Bệnh viện, thực hiện phối hợp nhiều chuyên khoa; đặc biệt hồi sức tích cực, những chuyên gia đầu ngành) thực hiện việc chẩn đoán căn nguyên và điều trị triệt để bệnh.

Bệnh nhân được chỉ định mổ cấp cứu (dự 
kiến cắt thùy dưới phổi phải); khi đặt ống nội khí quản 2 nòng hút rửa thì có máu chảy ra từ 2 bên phổi. Quyết định soi phế quản qua ống nội khí quản để xác định nguồn gốc chảy máu.

- Soi phế quản: Hình ảnh cục máu đông bít

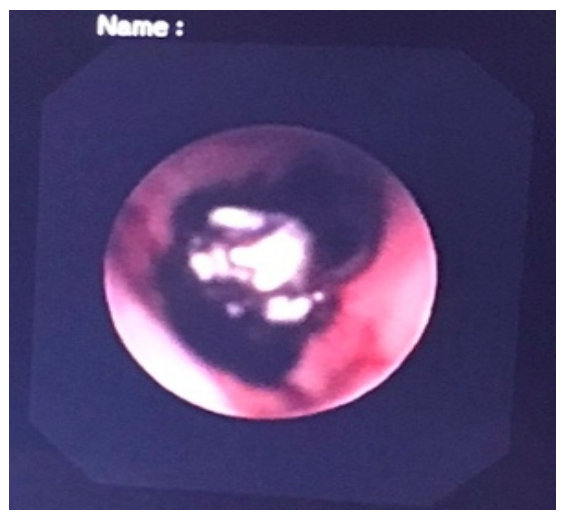

tắc phế quản gốc trái, máu đông bít tắc phế quản thùy trên, giữa, dưới phổi phải. Thực hiện hút rửa sạch máu đông kiểm tra thấy phế quản trùy trên, dưới phổi trái thông thoáng không còn máu chảy, máu chảy ra từ phế quản thùy dưới phổi phải.

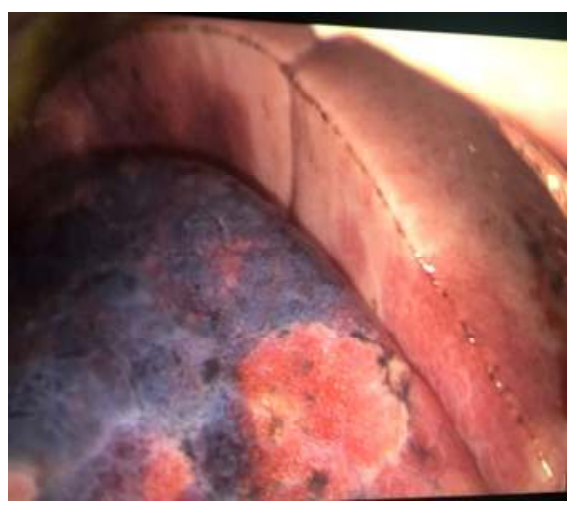

\section{Tổn thương thùy dưới} phổi phải.

- Chỉ định phẫu thuật: Mổ cắt thùy dưới

- Quy trình phẫu thuật:

+ Gây mê NKQ 2 nòng (ống Carlen), năm nghiêng bên trái $90^{\circ}$.

+ Mở ngực theo đường sau bên, vào khoang màng phổi qua khe liên sườn 5 , thấy thùy phổi trên và giữa bình thường, thùy dưới tím đen toàn bộ. Phẫu tích bộc lộ động mạch, tĩnh mạch và phế quản sau đó cắt dưới, kiểm tra phổi nở tốt, đặt 01 dẫn lưu, đóng thành ngực theo lớp giải phẫu. Thời gian phẫu thuật 120 phút.

- Giải phẫu bệnh lý sau mổ:

+ Đại thể: Vùng thùy phổi bị cắt bỏ có

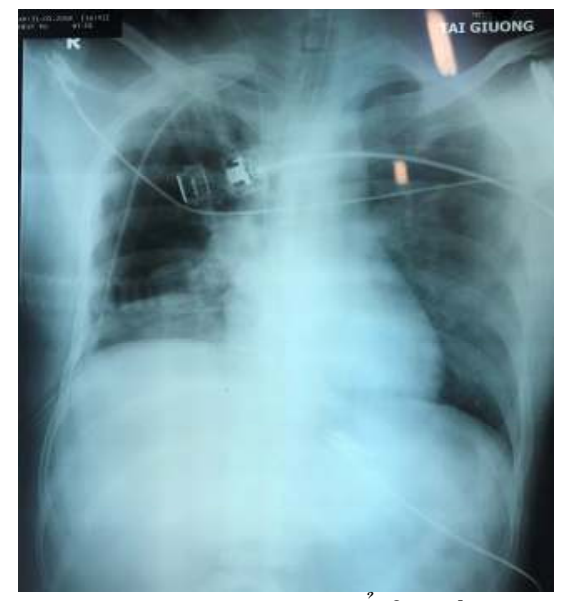

X quang sau mổ 3 giò ranh giới rõ, mặt ngoài nhẵn, màu đỏ sẫm. Diện cắt chắc, đặc, thả vào nước thùy phổi chìm. Có 1 khối kích thước $1 \times 1,2 \mathrm{~cm}$ mật độ mềm, ranh giới không rõ, nhu mô phổi xung quanh màu đỏ tràn ngập hồng cầu.

+ Vi thể: Trên các mảnh cắt cho thấy hồng cầu tràn ngập phế nang, có vùng thấy chất hoại tử bã đậu, vây xung quanh là tế bào khổng lồ, tế bào bán liên, lympho và tế bào bào xơ.

+ Kết luận: U lao (Tuberculoma).

- Kết quả sau mổ: Bệnh nhân được hồi sức, tập phục hồi chức năng, kháng sinh, truyền dịch, truyền máu, thuốc lao, rút dẫn lưu diễn biến ổn định.

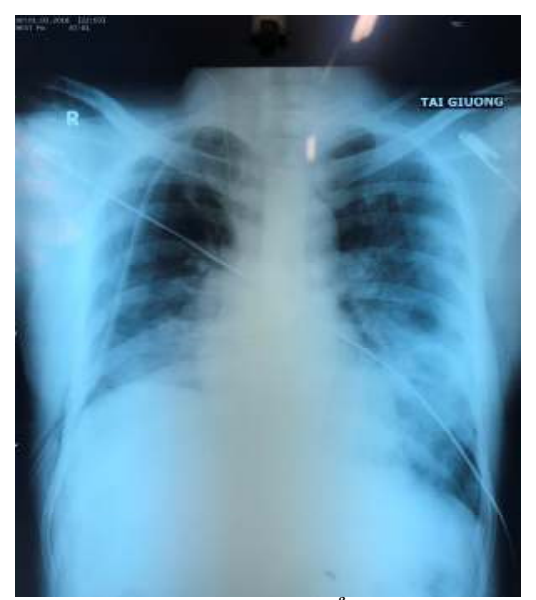

X quang sau mổ 24 giờ 


\section{BÀN LUẬN}

- Về nguyên nhân của ho ra máu: Ho ra máu là cấp cứu thường gặp trong các cấp cứu về bệnh lao và bệnh phổi. Ho máu là triệu chứng khiến bệnh nhân phải chú ý và tìm tới các cơ sở khám chữa bệnh sớm. Ho ra máu là máu từ đường hô hấp dưới (từ vùng dưới thanh môn) được ho khạc ra ngoài qua đường miệng mũi, ho từ nhiều mức độ khác nhau, có thể từ ít máu lẫn trong đờm tới ho máu nặng đe dọa tính mang khi số lượng máu từ 100 tới $600 \mathrm{ml}$ trong thời gian 24h. Ho ra máu là một triệu chứng có thể gặp của nhiều bệnh, trong đó chủ yếu là của một số bệnh phổi - phế quản. Có nhiều nguyên nhân gây ho ra máu, trong đó các nguyên nhân phổ biến bao gồm lao phổi, giãn phế quản, ung thư phế quản, các bệnh nhiễm khuẩn phổi ngoài vi khuẩn lao, do tắc mạch phổi hay nhồi máu phổi. Một số nguyên nhân ít gặp hơn bao gồm các bệnh lý của cơ quan tạo máu, các rối loạn đông máu, nguyên nhân do các can thiệp y tế, liên quan đến một số bệnh hệ thống (hội chứng Goodpasture, lupus ban đỏ...), các bệnh tim mạch (Hẹp khít van 2 lá, suy tim trái, cao áp động mạch phổi, nhồi máu phổi, tăng huyết áp, vỡ phình động mạch chủ ngực...) và ho ra máu không rõ nguyên nhân.

- Về chẩn đoán lâm sàng, nội soi và chẩn đoán hình ảnh: Trường hợp bệnh nhân trong báo cáo của chúng tôi bị ho ra máu nặng, đột ngột (khoảng 100-200ml/lần) cho thấy bệnh xuất hiện đột ngột ở người mà trước đó được coi là khỏe mạnh. Theo mô tả của người nhà và bệnh nhân, máu ho ra lẫn dịch đờm, màu đỏ tươi đông ngay phù hợp với đặc điểm lâm sàng của ho ra máu, không phải nôn ra máu. Khi nhập bệnh viện Phổi trung ương, bệnh nhân tỉnh táo, tiếp xúc tốt, da niêm mạc nhợt, không sốt, không ho ra máu, không khó thở, rì rào phế nang giảm ở đáy phổi phải. Khám thực thể, không phát hiện các vết bầm tím trên ngực và cổ (loại trừ chấn thương), không khó thở nên loại trừ dị vật đường thở, không phát hiện thấy các bất thường mạch ngoài da và cũng không thấy có bệnh tim liên quan, không thấy biểu hiện chảy máu trong khoang miệng hay răng vòm mũi họng nên nguyên nhân ho ra máu được xác định tại phổi là phù hợp.
Soi phế quản là một phương tiện hữu ích nhằm đánh giá tổn thương của khí phế quản, hình ảnh vùng tổn thương đã được chúng tôi thực hiện ngay sau đó. Kết quả soi phế quản cho thấy có máu đông ở phế quản gốc 2 bên, cản trở quan sát tổn thương ở phía dưới. Do vậy, muốn quan sát tổn thương phế quản phải lấy cục máu đông, đây là quyết định khó khăn vì có thể sẽ có máu chảy ra ồ ạt sau khi lấy bỏ máu đông. Dưới sự thông khí bằng ống nội khí quản 2 nòng; nhóm nội soi quyết định bơm rửa lấy cục máu đông, xác định nguồn chảy máu từ phế quản thùy dưới phổi phải. Đối chiếu với hình ảnh tổn thương trên bệnh phẩm trong và sau mổ chúng tôi cho rằng đây là một quyết định rất đúng đắn vì trong nhu mô phổi vần đang tiếp tục chảy máu.

Chẩn đoán hình ảnh là một xét nghiệm đóng vai trò quan trọng trong chẩn đoán nguyên nhân ho ra máu. Theo nhiều tác giả, hầu hết các dị tật của động mạch phổi, bệnh lý Lao phổi có thể được phát hiện bằng chụp $\mathrm{X}$ quang ngực và một chẩn đoán xác định có thể đạt được với CLVT hoặc MRI, ngoài ra CLVT có một vai trò quan trọng trong việc đánh giá bệnh tăng áp phổi. Eva Castanier và $\mathrm{CS}$ cho rằng ho ra máu do bất thường mạch máu phổi có thể được gợi ý từ các tổn thương không thấy dấu hiệu vôi hóa (loại trừ ho ra máu do lao), các dị vật bít tắc đường thở hay gãn phế quản. Tuy nhiên, trên phim phổi thẳng có tới một phần ba số bệnh nhân bị ho ra máu sẽ có $X$ quang bình thường. Các tác giả khuyên chụp động mạch nên được xem xét nếu nghi ngờ cao đối với dị dạng mạch máu tồn tại bất chấp hình ảnh âm tính trên CLVT. Trong trường hợp này, chúng tôi đã tiến hành chụp CLVT song không xác định được nguyên nhân của bệnh. Các phân tích sau mổ cho thấy lý do thất bại trong việc đánh giá trên phim chụp CLVT phổi vì tổn thương không phải bất thường động tĩnh mạch và cũng không phải là hình ảnh tổn thương điển hình của lao phồi.

- Về điều trị: Sau 4 ngày bệnh nhân nhập viện, trước tình hình diễn biến phức tạp của bệnh, nguy cơ tử vong cao, trước các bằng chứng về lâm sàng, chẩn đoán hình ảnh, chẩn đoán được đưa ra là: Ho ra máu nặng chưa rõ căn nguyên, chúng tôi đã quyết định phẫu thuật để điều trị 
bệnh. Quan sát khi soi phế quản trước mổ và hình ảnh đại thể trong lúc phẫu thuật cho thấy tổn thương toàn bộ thùy dưới, không thấy tổn thương ở hai thùy phổi còn lại. Kíp mổ quyết định cắt thùy dưới, khâu phục hồi lại phế quản trung gian; kiểm tra phổi nở tốt. Sau mổ bệnh nhân hồi phục tốt. Chúng tôi xin đưa ra một số chỉ định và chống chỉ định phẫu thuật trong điều trị Lao phổi:

1. Cấp cứu:

Chỉ định mổ cấp cứu (không mổ thì tử vong sẽ xảy ra và không tránh được)

Ho ra máu nhiều

Tràn khí màng phổi áp lực tự phát

2. Phẫu thuật khẩn cấp: chỉ định bao gồm

- Lao không tiến triển hồi phục, mặc dù điều trị thuốc chống lao đầy đủ

- Ho ra máu tái phát mà không thể điều trị bằng các phương pháp điều trị khác.

3. Phẫu thuật có chọn lọc

- Tổn thương khu trú của hang lao với sự tiếp tục bài tiết của vi khuẩn lao đã được xác định bằng vi sinh và DST sau 4-6 tháng điều trị bằng thuốc chống lao được giám sát thuốc chống lao

- M / XDR-TB đặc trưng bởi thất bại của

- Các biến chứng và di chứng của quá trình điều trị lao (bao gồm cả M / XDR-TB), bao gồm:

- Tràn khí màng phổi tự phát và tràn mủ tràn khí màng phổi

- Tràn mủ màng phổi có hoặc không có lỗ rò phế quản

- Aspergilloma

- lỗ rò nốt-phế quản

- Sỏi phế quản

- Viêm dày màng phổi hoặc viêm màng ngoài tim có suy hô hấp và tuần hoàn

- Hẹp khí quản và phế quản lớn sau lao

- Có triệu chứng và giãn phế quản mãn tính;

- Các chỉ định khác như loại bỏ các biến chứng của phẫu thuật trước.

Chống chỉ định phẫu thuật:

- Tổn thương rộng ở cả hai bên phổi

- Chức năng hô hấp suy giảm; bắt buộc lượng thở ra trong một giây ít hơn

$1,5 \mathrm{~L}$ trong trường hợp cắt thùy và ít hơn 2,0 L khi có kế hoạch cắt phồi.

- Suy tim phổi mức độ III-IV (phân loại chức năng của Hiệp Hội New York Hart)

- BMI lên đến 40-50\% trong giới hạn bình thường;

- Bệnh nặng kèm theo (tiểu đường mất bù, loét dạ dày tá tràng, suy gan hoặc suy thận);

- Lao phế quản thể hoạt động

- Về chẩn đoán xác định: Dựa trên các triệu chứng lâm sàng, nội soi và chẩn đoán hình ảnh, chúng tôi mới chỉ khẳng định được là ho ra máu nặng. Các quan sát tổn thương trong lúc phẫu thuật cho biết nguyên nhân ho ra máu là do chảy máu từ nhu mô phổi. Hình ảnh đại thể cho thấy giống một ổ nhồi máu phổi, chúng tôi không tìm thấy bất thường các mạch lớn. Trên vi thể cho thấy có hình ảnh chảy máu toàn bộ các phế nang, với các thành phần của u lao. Với các bằng chứng như trên, chẩn đoán cuối cùng của ca bệnh là Chảy máu thùy dưới phổi phải do lao là hoàn toàn xác đáng.

\section{KẾT LUẬN}

Ho ra máu nặng ở không hiếm tuy nhiên ho ra máu nặng có nguyên nhân do lao lại càng hiếm. Trong báo cáo này, chúng tôi muốn giới thiệu một ca bệnh hiếm gặp, có tiên lượng xấu, nguy cơ tử vong bất kỳ lúc nào song nhờ sự phối hợp chặt chẽ giữa nhiều chuyên khoa của Bệnh viện, nhiều chuyên gia giàu kinh nghiệm nên bệnh nhân đã được điều trị thành công đồng thời cũng cho thấy tính chất đa dạng và phong phú về bệnh học phổi tại Việt Nam.

\section{TÀI LIẸU THAM KHẢO}

1. Gautam Ahluwwalia (2011), Pulmonary Vascular Malformations. Textbook of Pulmonary \& Critical Care Medicine. Vol 2, Jaypee Brothers Madical Publishers, 127-135.

2. Eva Castanier, Xavier Gallardo, Jordi Rimola, Yolanda Pallardo et al (2014), Congenital and Acquired Pulmonary Artery Anomalies in the Adult: Radiologic Overview. RadioGraphics, Volume 34, No 7, 1527- 1332.

3. Kang, M.W., Kim, H.K., Choi, Y.S., Kim, K., Shim, Y.M., Koh, W.J. et al. Surgical treatment for multidrug-resistant and extensive drug-resistant tuberculosis. The Annals of thoracic surgery. 2010;89: 1597-1602. 